\title{
THE YOM KIPPUR WAR: AN ANALYSIS OF EGYPT'S SURPRISE ATTACK BY A MILITARY-TECHNOLOGICAL STANDPOINT ${ }^{1}$
}

\author{
Eduardo Maia (PUC-MG) ${ }^{2}$
}

Resumo: Este artigo tem por objetivo analisar o ataque surpresa empregado pelo Egito, sobre Israel, na Guerra do Yom Kippur (1973). Para tanto, partiu-se das contribuições de Handel (2003) e Dunstan (2003, 2009) como pilares fundamentais à análise proposta dos usos e funcionamento de ataques surpresa, e da formação militar de Israel e do Egito em duas épocas distintas, respectivamente: a Guerra de 1967 e a Guerra de 1973. A metodologia empregada foi a de estudo de casos comparados para que se pudesse testar a hipótese levantada. Conclui-se que, ao se valer de uma evolução em termos tecnológicos e militares, o Egito foi capaz de empregar um ataque surpresa contra Israel de forma relativamente satisfatória.

Palavras-Chave: Ataque Surpresa. Militar-Tecnológico. Yom Kippur.

\begin{abstract}
This article aims to analyze the surprise attack employed by Egypt, on Israel, in the Yom Kippur War (1973). For that, I started with the contributions of Handel $(2003)$ and Dunstan $(2003,2009)$ as fundamental pillars to the proposed analysis of the uses and functioning of surprise attacks, and of the military formation of Israel and Egypt in two different periods, respectively: the 1967 War and the 1973 War. The methodology used was that of comparative case studies so that the hypothesis raised could be tested. It is concluded that, by using technological and military developments, Egypt was able to employ a surprise attack against Israel in a relatively satisfactory manner.
\end{abstract}

Key-Words: Surprise attack. Military-Technological. Yom Kippur.

\footnotetext{
${ }^{1}$ O presente trabalho foi realizado com apoio da Coordenação de Aperfeiçoamento de Pessoal de Nível Superior - Brasil (CAPES) - Código de Financiamento 001 - This study was financed in part by the Coordenação de Aperfeiçoamento de Pessoal de Nível Superior - Finance Code 001.

2 Doutorando em Relações Internacionais - PUC-MG
} 


\section{INTRODUCTION}

Why do states attempt to surprise their adversaries? What do they expect to achieve with surprise? Does surprise always work or do they eventually fall apart because they were not well planned? Answering all these questions seems like a tricky thing to do when looking for a binary or simplistic answer. In fact, surprise attacks are complex. It can be thought as a recurring event in human as well states - life. Surprise can be thought of "an act or development [that] has taken place contrary to our expectations, thus providing our assumptions to be ill founded". On the other hand, this same surprise can come without any kind of "warning", without any expectation of its occurrence. (KAM, 2004, p. 7).

This paper aims to analyze and understand the use of the so-called "strategic surprise" employed by Egypt (along with Syria), upon Israel, in the Yom Kippur War, by a military-technological standpoint. Accordingly, this paper is based, fundamentally, on the contributions of Handel (2003) and Dunstan (2003, 2009) about the analysis of the concept and uses of strategic surprise and warning time, as well as the military conditions and context of Israel and Egypt in 1973, respectively. In this sense, the guiding question of this paper is: What could influence Egypt's capability to employ a successful surprise attack upon Israel, in the Yom Kippur War? The hypothesis is that an improvement and/or enhancement of military-technological matters gave Egypt the necessary capacity to employ a successful surprise attack upon Israel by the year of 1973 .

The first session makes considerations about the fait accompli strategy along with the surprise attack strategy. In fact, the two strategies, although separately treated by some authors in the literature, are intrinsically linked at their core, as will be seen. Still, the first section brings an analysis based on Handel (2003) understands of an attack acting as a "force multiplier" in a given conflict.

Posteriorly, section two clarifies the link between the chances of success of a surprise attack and the military-technological evolution through time. The period of warning time is proportionally linked to this military-technological evolution as well. Section 3 makes an overview of the main events of the 1973 war. 
Section 4 is in charge of comparing the military availability of forces by the time of the Six Day War (1967), to the military availability of forces by the time of the Yom Kippur War, from both Egypt and Israel, to make possible the hypothesis testing of the present paper.

\title{
1. Surprise Attack and the Fait Accompli Strategy: Two Sides of the Same Coin
}

According to Maia (2020), the fait accompli strategy is treated and understood, directly or indirectly, in different ways by different authors who deal with the topic. (MAIA, 2020). George and Smoke (1974) provides the first and broadest definition based on Tarar's (2016) contributions, where the authors would describe the purpose of the fait accompli:

\begin{abstract}
The fait accompli strategy, it may be noted, is the most "rational" way to initiate an effort to change the status quo when the initiator believes that a strong potential defending power has written off the territory in question altogether or has made what appears to be a firm decision to limit his aid to military and economic assistance and diplomatic support. A maximum effort by the initiator to achieve his objective quickly confronts the potential defending power with a fait accompli, giving him little or no time to reconsider and reverse his policy of noninvolvement. From the standpoint of the initiator, the fait accompli strategy may well appear the least risky way in these circumstances to change the status quo. (GEORGE \& SMOKE, 1974 apud TARAR, 2016, p. 2).
\end{abstract}

In other words, the side willing to initiate a quick status quo change, in expectation that the other side will not take any significant action against this attempt, may choose the fait accompli strategy as long as it believes it is the least risky way to accomplish its objectives. George (1991), making considerations about the strategies of "crisis management", brings a similar definition to the term, when it says that the fait accompli strategy may be recommended when:

(...) the challenger is confident that the adversary is not committed to defend the position under dispute, that he has for all practical purposes written it off, then the challenger may decide that quick, decisive action is not only the most efficient way to change the status quo but is also risk-free insofar as the likelihood of unwanted escalation is concerned. (GEORGE, 1991, p. 382).

The above-mentioned definition needs two parallel considerations. First, although the adversary is not "committed" to defend its position, or the status quo, 
the challenger must recognize that the same adversary may be willing to defend it, as soon as the fait accompli takes place; second, even considering the above mentioned situation, the challenger of the status quo may conclude that, to quote George (1991), "his quick and decisive action will change the status quo so quickly that the defender will not have time to muster the capabilities to resist the fait accompli”. (GEORGE, 1991, p. 383).

Another useful theoretical contribution about the use of the fait accompli strategy, lies at Altman's (2017) definition of the term. Similar to George's (1991), Altman (2017) states that "A fait accompli imposes a limited unilateral gain at an adversary's expense in an attempt to get away with that gain when the adversary chooses to relent rather than escalate in retaliation". (ALTMAN, 2017, p. 882). In this sense, the fait accompli strategy would be unsuitable for "maximalists" aims, the ultimate goal of challenger of the status quo is to avoid escalation rather than bear the costs of a full war. (ALTMAN, 2017; SCHELLING, 1966; SCHELLING, 1960).

Within the framework of the fait accompli strategy, there is the dimension of the "military fait accompli", understood as the use of the fait accompli strategy within a military, or war, context. (TARAR, 2016; ALTMAN, 2017). Tarar (2016) understands that a dissatisfied leader would try some costly change to the status quo, through a fait accompli, for two main reasons. The first one is the (1) "informational explanation". The informational explanation "suggests that when the defender is uncertain about the dissatisfied leader's marginal cost of engaging in a fait accompli, then in crisis bargaining she typically makes a risky offer that low-cost types reject by engaging in a fait accompli”. (TARAR, 2016, p. 2). In other words, the "defender's uncertainty about the feasibility (costliness) of a fait accompli leads to an unwillingness to offer sufficient concessions", then, the challenger of the status quo chooses to employ the fait accompli. (ALTMAN, 2017 , p. 883). The second explanation is the "commitment-problem explanation". Tarar (2016) advocates that coercion. (TARAR, 2016, p. 2 - emphasis added). 
That is, after a cost-benefit consideration, the challenger who's considering to employ the fait accompli, may do so when the benefits of resorting to it is bigger than the costs, then the challenger engages into a fait accompli without making any threats or signals to his opponent. About the commitmentproblem explanation, Altman (2017) says that it "posits a first-strike advantage". In his own words: "Challengers impose faits accomplis suddenly and by surprise in order to avoid having the defender make military preparations that would increase the costs of a future fait accompli" (ALTMAN, 2017, p. 883 - emphasis added). In this sense, it is possible to realize that the fait accompli technique, besides being a way of changing the status quo, has the essence of "surprise" in its core.

In the same way of Altman (2017) and Tarar (2016), Paul (1994), making considerations of the strategies that can be used for war initiations, expresses that:

\begin{abstract}
A key element of a limited aims/fait accompli strategy may be surprise, which, if properly employed, can destroy a good portion of the defender's unalerted forces. This can result in the defender being unable to use its forces efficiently and effectively, while the attacker maximizes its own capabilities and firepower. (...). The important characteristic of a surprise attack is that it allows the initiator the choice of time, place, and method of engagement, while denying all these to the opponent. (PAUL, 1994, p. 29 - emphasis added).
\end{abstract}

The aforementioned consideration makes clear that one of the reasons that makes the fait accompli strategy highly interesting for the status quo change, at low cost, is the element of surprise. In this sense, by accepting the premise of the fait accompli strategy as a surprise attack, we shall make some considerations concerning what can be understood as a "surprise attack".

Kam (2004) defines a surprise attack through three main elements. The first one considers the surprise attack as a (1) "military act that is not consistent with the victim's expectations and assumptions". (KAM, 2004, p. 8). Which means that a surprise attack is, fundamentally, a military attack upon an unguarded or unsuspecting adversary. The second one indicates that a (2) "surprise attack implies a failure of advance warning". (KAM, 2004, p. 8-9). In other words, this second definition indicates the failure of the defender's side in anticipating or avoiding the attack. The third and final element of a surprise attack, lies on the 
(3) "victim's failure to meet the danger adequately. In this sense, the degree of surprise can be deduced from the victim's level of preparedness". (KAM, 2004, p. 8-9).

So far, those three elements focus on the victim's actions and perceptions about the sudden attack, implying, to some extent, that the "fault" of being military caught by surprise, lies on the victim's lack of previous information and knowledge of the attack, thus, failing to perceive some facts properly. Bar-Joseph and McDermott (2017) are consonant with this view as long as they consider that, "being caught by surprise attack means that the victim does not appreciate, whether, when, where or how the adversary will strike'”. (BETTS apud BARJOSEPH, MCDERMOTT, 2017, p. 9). However, as shall be seen later in this paper, even though the aforementioned considerations may be true, the success of a surprise attack also depends on the attacker's abilities and, maybe more importantly, the military capabilities of doing it.

The whole matter of a military surprise attack also lies on the considerations about the so-called "strategic surprise". Levite (1987) defines "strategic surprise" as "the sudden realization that one has been operating on the basis of an erroneous threat perception”. (LEVITE, 1987, p. 1). The alluded "threat perception" refers to any kind of significant threats to a state's security. In the words of Bar-Joseph and McDermott (2017): "it [the strategic surprise definition] encompasses the misperception not only of military threats but also of political, diplomatic, social, economic, and any other sudden developments that might have a significant impact on a given state's security. (BAR-JOSEPH, MCDERMOTT, 2017, p. 9). In this sense, the term "strategic" encompasses all of the threats that some state may face regarding its security, especially when it concerns sudden attacks from other states.

\subsection{Strategic Surprise as a Force Multiplier}

One of the main advantages of the strategic surprise is that it acts as a "force multiplier". (HANDEL, 2003). According to Michael Handel (2003), the 


\section{Universidade Federal Fluminense \\ Instituto de Estudos Estratégicos}

surprise acts as a force multiplier to the challenger state in a military weaker position, relatively to the adversary ${ }^{3}$. In Handel's (2003) words:

In compensating for the weaker position of the attacker, it will act as a force multiplier that may drastically reverse the ratio of forces in the attacker's favor. Stated in more general terms, the numerically inferior side is able to take the initiative by concentrating superior forces at the time and place of its choosing, thereby vastly improving the likelihood of achieving a decisive victory. (HANDEL, 2003, p. 2).

In this sense, the incentive to employ the surprise comes, essentially, from the weaker side of the conflict, while "stronger armies, however, lack the 'natural incentive' to employ such methods, and must therefore make a conscious effort to exploit the full potential of strategic surprise if they are to maintain a superior position and achieve more decisive results at a minimal cost". (HANDEL, 2003, p. 2).

Nevertheless, the achievement of complete and a hundred per cent effective surprise does not guarantee, necessarily, the victory in the war. (WIRTZ, 2003; HANDEL, 2003). "Surprising the enemy per se does not necessarily mean that the attacker has reaped the fullest possible benefits or will be assured ultimate victory". (HANDEL, 2003, p. 2).

One of the reasons Handel (2003) points out for this aforementioned fact is that the attacker is so surprised by the effectiveness of the surprise attack, "that he is caught unprepared to exploit fully the opportunity it presents". Two examples illustrate the unexploited opportunity of an attack: The Pearl Harbor attack by the Japanese whom did not make consecutive on US oil deposits, and, more canonically, the Egypt and Syrian attack upon Israel, in 1973. Concerning the latter, Handel (2003) expresses that "rigidly adhering to the original plan of attack, they prematurely halted their advance following the first phase of the attack, when they could have continued to make considerable progress at little cost to themselves". (HANDEL, 2003, p. 2). To quote Clausewitz (1976): "It would be a

\footnotetext{
${ }^{3}$ Some theorists of the strategy of surprise (Handel, 2003; Wirtz, 2003; Betts, 2003, Kam, 2004; Bar-Joseph and McDermott, 2017; Paul, 1994) consider that the probability of making use of surprise is greater when the state willing to do it, is the military weaker side of the conflict. Theoretically, the military stronger side would not need to be concerned in strike first, due to its advantage position. The aim of this paper, however making considerations about the Yom Kippur War, is not analyze the surprise attack of Egypt from the perspective of the military weaker side. Given that both Egypt and Syria coordinated it forces, it would take a lot of time comparing the three sides of the conflict, to assert who was the weaker side of the war, and that is not the core objective of the present paper.
} 
mistake, therefore, to regard surprise as a key element of success in war". (CLAUSEWITZ, 1976, p. 198-199).

In short, the accomplishment of the surprise attack itself, "is the first phase of planning; the second must consist of detailed preparations for the best possible exploitation of the projected surprise attack". (HANDEL, 2003, p. 2). In this sense, as long as one can exploit the best possible outcome of a surprise attack, it "temporarily suspends the dialectical nature of warfare (or any other strategic contest) by eliminating an active opponent from the battlefield". (WIRTZ, 2003, p. 98-99). In other words, Wirtz (2003) considers that a successful surprise attack eliminates the chances of an opponent who would do anything in its power to stop his adversary from reaching its objectives. (WIRTZ, 2003).

\section{Surprise Attack and its Relation to Military-Technological Advances}

According to Handel (2003), before the revolution on technologicalindustrial matters, the fast movement of troops and weapons through large distances, in a short period, was practically (virtually) impossible. The slow mobilization of troops and weapons in war could provide a series of clues of an adversary's intentions. (HANDEL, 2003, p. 3). Nonetheless:

\footnotetext{
With the advent of technology came the ability to achieve strategic surprise, as well as a change in the modes and aims of surprise, which, in its strategic form, is a much more complex phenomenon. Surprise could now be achieved simultaneously on several levels: in timing, the place of attack, rapidity of movement, the use of new technologies delivery and weapons systems, the frequent appearance of new doctrines and innovative tactics to match the new technologies, as well as in the choice of the political-military goals for war itself. (HANDEL, 2003, p. 4 - emphasis on the original).
}

The fast evolution of technology and its dissemination through every aspect of life, including military and security matters, made possible the achievement of surprise in a way never seen before. Before the advent, and evolution, of technology, the achievement of surprise related to timing, place and rapidity of the attack, was relatively hard due to the delay presented by the lack of resources. Still according to Handel (2003): "When employed in conjunction with the enormously increased capacity of conventional firepower, the efficient, rapid means of transportation multiplied the power with which one could attack at 
a selected point and catch one's adversary completely off guard". (HANDEL, 2003, p. 3).

The surprise attacks arising from technological improvements in military terms can be divided into two distinct categories. The first one comprises the (1) "secret development of 'one' large system which is not deployed on the battlefield itself, such as Ultra ${ }^{4}$ and the atomic bomb"5. The second one comprises the (2) "the massive battlefield deployment of a new weapon system, such as the Zero ${ }^{6}$ or the T-34 ${ }^{7}$, which takes considerable time and is difficult to conceal". (HANDEL, 2003, p. 3). As will be seen in the later sections, the surprise attack of Egypt upon Israel, in 1973, belongs to the second category.

The technological improvements are not just about ground weapons, such as tanks or howitzers, or brand-new aircraft modellings, but they also comprise the invention and enhancement of Intercontinental Ballistic Missiles (ICBM's) and nuclear weapons. This kind of weapons are capable of being operational in minutes, meaning, "a strategic surprise could be both the beginning and the end of a war". (HANDEL, 2003, p. 3).

\subsection{The Role of Strategic Warning}

For a state willing to change the status quo in a quick and decisive way, plan a surprise attack could be the very best option in hand. Nevertheless, maybe as more important than resort to a surprise attack, is to be prepared to anticipate one. Anticipate an attack is still one of the hardest things to do in the role of strategic warning. (HANDEL, 2003).

According to Bar-Joseph and McDermott (2017), the so-called strategic warning has a dual purpose. The first one is (1) "to inform policymakers that their deterrence strategy has ceased to be effective and that the enemy has decided to change the status quo using force". This kind of decision generally takes place a long time before the operationalization of the attack. Sadat, for example, has

\footnotetext{
${ }^{4}$ Designation of the British Intelligence of the code breaking effort in the Second World War. (HANDEL, 2003).

${ }^{5}$ Being considered, by Handel (2003), a type of technological surprise of extremely difficulty of discovery or anticipation. (HANDEL, 2003, p. 5).

${ }^{6}$ Japanese aircraft used in World War II.

7 Type of Russian Tanks.
} 
decided the attack on Israel one year before the materialization of the Yom Kippur War, on October 1972. (BAR-JOSEPH, MCDERMOTT, 2017, p. 11). The second purpose of the strategic warning is (2) "to provide a high-quality warning before the actual attack takes place". This quality is measured by two main standards: volume and timing. The volume indicates how much information is enough to convince that the threat of attack is real. In addition, timing is a necessary condition for the victim to take the necessary measures against the attack, in sufficient time. (BAR-JOSEPH, MCDERMOTT, 2017).

Although technology has evolved significantly in the past decades, "the warning gap between the attacker and defender has remained as wide as in the past and still favors the offense over the defense". (HANDEL, 2003, p. 6). According to Handel (2003), one of the reasons is because the "intelligence work $(\ldots)$ is still based upon the human factor", therefore, even the most advanced technology is still dependent on the labor-intensive intelligence work. (HANDEL, 2003, p. 6).

Figure 1. Strategic Surprise and Technological Evolution: The Reduction of Warning Time

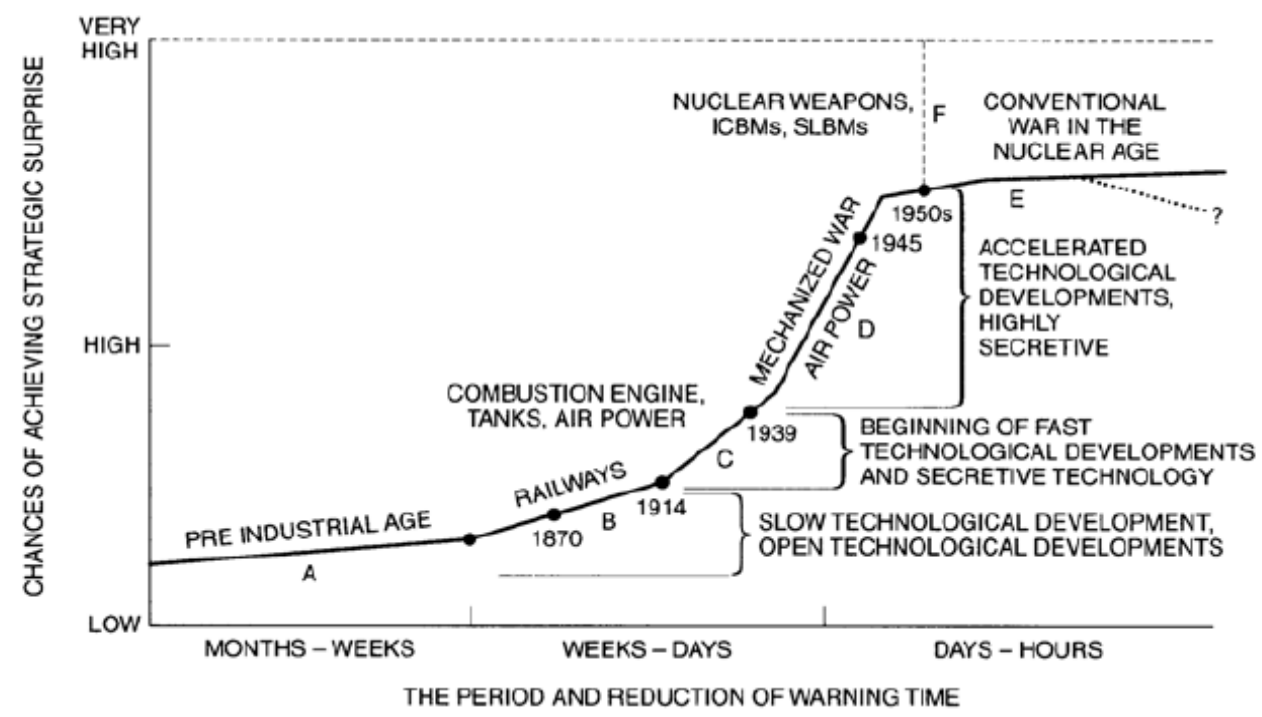

Source: Handel (2003, p. 7)

\footnotetext{
8 “A. Pre-industrial age. Slow mobility, limited firepower. Chances of a successful strategic surprise very low. (1870). B. Railway age. Increased mobility, mobilization. Slow increases in firepower. Chances of a successful strategic surprise low but possible. (1870-1916) C. Combustion engines, tracked vehicles and tanks, rise of air power and firepower. Mechanized warfare blitzkrieg. Chances of strategic surprise high. (1916-1939) D. Further improvement in mobility and firepower. Chances of strategic surprise high- but also improvements to intelligence. (1939 to present) E. Development of nuclear weapons and later ICBMs and SLBMs par excellence the weapons of strategic surprise. War can be decided-theoretically and
} 
Figure 1 above shows the relation between the time needed to achieve strategic surprise based on available technology. As technology increases over time, so does the chance of strategic surprise to be successful. From a time when the intention of surprise some adversary could take weeks or even months, thus lowing the probability of a successful attack; as technology grew exponentially, with the advent of the internal combustion engine, air power, nuclear weapons and the accomplishment of an increasingly cutting edge technology, now a surprise attack could take days or hours to be employed, with a high probability of being successful.

\section{The Yom Kippur War: An Overview ${ }^{9}$}

The Arab world began the 1970s still in strong unrest due to the events of the past few decades. The proclamation of the State of Israel, and the subsequent war on account of this fact, in 1948 together with the 1967 War, were still alive in Arab memory as a great moral and, above all, territorial loss. Especially for Egypt and Syria, the need to reaffirm Arab rhetoric and the retaking of the territories occupied by Israel in the Six Day War were shown as a need that went beyond the question of Palestine: a need and an "instinctive desire to avenge the loss and to strike back [the defeat imposed by Israel]". In this sense, for these two states, "another war [had shown itself] to be inevitable and in fact necessary as the only way their pre-1967 borders would be restored". (KAMRAVA, 2005, p. 125).

practically - in minutes. (1945 to present) F. Improvements in conventional mobility and firepower. Increased importance of air power. High chances of success for strategic surprise-but slowed increase given the technical developments of reconnaissance (air photography, satellites, electronic intelligence). Potential for surprise is somewhat leveled off by reconnaissance and familiarity with tactics of blitzkrieg. Yet, despite all the technological improvements that may help the defense, the basic problems of anticipating an attack are perceptual and psychological and remain without a satisfactory solution". (HANDEL, 2003, p. 7).

${ }^{9}$ This specific section makes a use and brings considerations about the Yom Kippur War based on a recent master thesis of Maia (2020) (see Bibliography) that possess sections in charge of analyzing the war and its results. Given that the aim of the section is to present just an overview of the conflict, the use of the author considerations will be of great value for this end. The quotations from other authors are properly indicated on the text. 
The responsibility for carrying out this mission, and successfully leading it, would now be in the hands of Anwar Sadat, who succeeded Egypt's presidency after Nasser's death. In addition to balancing Egypt's internal political conflicts (along with economic and social ones), Sadat needed a reputation and popularity equal to Nasser, which he did not yet have, to achieve the objectives that were on the agenda. Furthermore, Israel's occupation of both the Sinai and the Suez Canal was eroding beyond Egyptian political capital. The country's economy was increasingly compromised due to the great military mobilization by Egypt in the Sinai desert. In the words of Kamrava (2005): "Getting the Sinai back was now more than a matter of political or even national vindication. Increasingly, it was a matter of economic survival". (KAMRAVA, 2005, p. 126).

Anwar Sadat, who had recently assumed the presidency of Egypt, would not yet be in a position to sign any agreement with Israel, as territories vital to the former were still occupied by the Jewish neighbor. Thus, and considering this whole scenario, Sadat should decide whether to go to war against Israel again or not. Thus, in July 1972, Sadat expelled approximately fifteen (15) thousand Soviet military advisers, who had been assisting in the reconstruction of Egyptian armed forces since the 1967 war and severed diplomatic relations with Jordan under a relatively relevant small pretext - a proposal made by King Hussein to create a Jordanian Federation that would have sovereignty over the Palestinians. (KAMRAVA, 2005, p. 127-128).

In the eyes of the Prime Minister Golda Meir, and other members of the Israeli hardliners, such actions by Sadat were interpreted as a sign of weakness, both strategic and military, because "the Egyptians, who had been so decisively routed back in 1967, could not pose a serious threat to Israel now that they had lost their Soviet patrons and Jordanian allies". However, Sadat's intention was precisely to gain the freedom and leeway necessary to bring war to Israel with Syria. (KAMRAVA, 2005, p. 128).

Thus, in the early hours of October 6,1973, "in the middle of the Muslim holy month of Ramadan and the Jewish Yom Kippur [Day of Atonement]" (KAMRAVA, 2005, p. 128; DUNSTAN, 2003, p. 14), forces Egyptians and Syrians attack, in a coordinated way, the Israeli positions in the eastern part of the Suez Canal and the Golan Heights, respectively. As far as Sinai is concerned, Egypt 
Universidade Federal Fluminense

Instituto de Estudos Estratégicos

used seven hundred tanks to carry out the attack and, at the end of the day; the fortifications of the Bar-Lev Line were finally broken. On the Syrian side, Israeli losses were even greater, "by the end of the first day's fighting, the entire Golan Heights had been recaptured by Syrian forces". In order to prevent Syrians from gaining more territory, Israel tried to respond with air strikes, but did not achieve the desired success. In Sinai, the Israeli counterattack, "which resulted in one of the biggest tank battles since World War II", also failed to drive Egypt out of Suez. In short, in the first three days of the battle, it seemed that the Egyptian and Syrian victory was guaranteed. (KAMRAVA, 2005, p. 128).

\section{The Six Day (1967) and the Yom Kippur (1973) Wars: Differences Between Egypt and Israel by a Military and Technological Standpoint}

To be able to analyze Egypt's surprise attack upon Israel, in 1973, by a military-technological standpoint, it is necessary to compare it to some other event that presents similar conditions of conflict, and military availability, regarding the 1973 war. The Six Day War $(1967)^{10}$ was the last major war between the two countries and, therefore, has the capacity of being comparable in terms of the latest available military and technological forces of the two states, before 1973. Hence, it is necessary to bring some statistics about the military forces of the two sides by 1967, to compare it to the forces of 1973 .

\subsection{Military Forces of Egypt and Israel before the Six Day War (1967)}

At first sight, the military force of Egypt before the 1967 war, was slightly smaller relatively to Israel, and the combined forces of the whole Arab world seemed "overwhelming" against Israel (DUNSTAN, 2009) as Table 1 shows:

\footnotetext{
${ }^{10}$ For the reasons that led to the Six Day War, and its aftermath, see, for example: Maia (2020), Kamrava (2005) and Dustan (2009).

* The total included 522 Shermans; 184 AMX-13s; 250 M48 Pattons and 338 Centurions. The APCs were all World War II Vintage M3 half-tracks. (DUNSTAN, 2009, p. 25 - footnote).

** 196 of these were frontline strike aircraft. (DUNSTAN, 2009, p. 25 - footnote).
} 
Table 1. The Military Forces of Israel and Arab States by 1967

\begin{tabular}{|c|c|c|c|c|c|c|}
\hline & Israel & Egypt & Jordan & Syria & Iraq & Arabs \\
\hline Manpower & 250.000 & 210.000 & 55.000 & 63.000 & - & 328.000 \\
\hline Brigades & 25 & 22 & 10 & 12 & - & 42 \\
\hline Artillery & 745 & 575 & 263 & 315 & - & 960 \\
\hline Tanks & $1.294^{*}$ & 1.300 & 288 & 750 & - & 2.330 \\
\hline APCs & 2.000 & 1.050 & 210 & 585 & - & 1.845 \\
\hline SAMs & 50 & 0 & 0 & 0 & - & 160 \\
\hline AAA & 550 & 950 & 143 & 1.000 & - & $2.000+$ \\
\hline Aircraft & $286^{\star \star}$ & 431 & 28 & 127 & 106 & 692 \\
\hline
\end{tabular}

According to Dunstan (2003), despite their combined overpowering number of troops and military weapons, the Arabs had several operational and doctrinal difficulties, "with virtually no political or military cooperation at any level between the various countries". Furthermore, "there was no common plan to invade Israel in a coordinated campaign". (DUNSTAN, 2009, p. 25).

In 1967, Israel's army on full mobilization consisted around 250.000 troops. From 25 brigades, nine (9) of it were armored, "two [2] were fully mechanized and ten [10] were infantry", partially mechanized and four paratroops that acted like assault elite troops. Furthermore, in the Southern Command, five (5), of nine (9) brigades, were armored, three (3) were mechanized or motorized, and one (1) was a paratroop in a mechanized role. As backup, "there were three [3] brigades as operational reserve, one [1] armored and two [2] infantry". (DUNSTAN, 2009, p. 25-26).

\begin{abstract}
In total, Southern Command had 70,000 troops and approximately 800 tanks with nearly all of the most modern types in the IAC inventory. The Israeli Army was well motivated since many believed that the very existence of Israel was at stake but much of its equipment was of World War II vintage. (...). However, it had invested heavily in modern communications equipment that allowed for a flexible command and control system: a structure that suited the Israeli temperament with all levels of command being able to display initiative in any overall offensive plan from an infantry company to an armored brigade. (DUNSTAN, 2009, p. 26 - emphasis added).
\end{abstract}

On the other side of the border, Egypt's army, in 1967, on full mobilization consisted of 210.000 troops: some 100.000 troops were at the Sinai Peninsula and approximately 50.000 men were in Yemen. On the Sinai front, it had around 
"six (6) divisions with 930 tanks, 200 assault guns and 900 artillery pieces". Nevertheless, none of these positions was mutually supportive "and had been starved of funds since the bulk of the Egyptian military operational budget had been committed to the forces in Yemen for several years". Moreover, Egypt possessed a tendency of being "defensive in nature", due to the "inadequate training and lack of mechanization among its infantry units". (DUNSTAN, 2009, p. 26).

In sum, by the brink of the 1967 war, Israel was hugely ahead in a militarytechnological matter, relatively to its Arab neighbors, especially Egypt, that besides having a lower quality in its military materials also had no coordination among its units.

\subsection{Military Forces of Egypt and Israel before the Yom Kippur War (1973)}

\subsubsection{Israel}

By 1973, six years after the stunning defeat posed to the Arab world, as well its morale, Israel possessed an active army of around 75.000 troops. Since 1967, the Israeli armed forces mobilization grew from 250.000 to 350.000 , "and over 30 brigades could be deployed, grouped into division-sized task forces (Ugdas)". (DUNSTAN, 2003, p. 26). During "peacetime", one Ugda was in the front of Sinai and the other on Golan. "The other Ugdas were based on training establishments or other cadres and their commanders could be reservists". (DUNSTAN, 2003, p. 26). An overview of the detailed equipment possessed by the Israeli Defense Force (IDF) is as it follows: 
Table 2. Overview of Detailed Military Equipment - Israeli Army (IDF) (1973)

\begin{tabular}{c|c}
\hline EQUIPMENT & APPROXIMATE NUMBER \\
\hline Manpower & $350.000(75.000$ active $)$ \\
Tanks & $2.000(1.000-$ British Centurions \\
Combat Aircrafts & $550-(130$ F-4 Phantoms; 170 A- \\
& 4 Shyhawks; Uncounted Mirage \\
Jets $)$
\end{tabular}

As it can be seen, Israel still possessed a larger number of equipment and military capacity compared to the year of 1967 . However, on the other hand, Egypt also increased its military capacity, as follows.

\subsubsection{Egypt}

In the year of 1973, the Egyptian armed forces comprised around "1.200.000 troops, with 66.000 officers and 1.134.000 NCOs and enlisted men with approximately half that number deployed for the coming offensive". Moreover, "five infantry divisions and a number of independent and armored brigades backed by three mechanized and two armored divisions were deployed along the Suez Canal. Each infantry division was three brigades strong and supported by a brigade of 120 tanks". (DUNSTAN, 2003, p. 24). An overview of the detailed equipment possessed by the Egyptian Army was as follows: 
Table 3. Overview of Detailed Military Equipment - Egyptian Army (1973)

\begin{tabular}{c|c}
\hline EQUIPMENT & APPROXIMATE NUMBER \\
\hline Manpower & 1.200 .00 \\
Tanks & 2.200 \\
Artillery Pieces & 4.000 \\
MBTs & 1.700 \\
AFVs & 2.000 \\
SAM Batteries & 850 \\
AA Guns & 2.500 \\
Combat Aircraft & 400 \\
Transport Planes & 60 \\
Helicopters & 140 \\
MiG-17 & 1 \\
MiG-21 & 1 \\
SU-7* & 1 \\
Mirage III Squadrons* & 2 \\
Hawker Hunter & 1 \\
Squadron* & \\
Source: Withdraw and adapted from Dunstan (2003, p. 24)
\end{tabular}

At this point, it should be clear the large and wide increase in military issues like equipment and personnel that Egypt has undertaken since the last defeat, in 1967. However, that was not the only changes Egypt has made. Looking back to its defeat in the Six Day War, the Arab country identified two main areas of weakness: the ineffectiveness of its Air Force in comparison to Israel, and its similar inferiority concerning its armored groups, "both in the quality of its weapons and the training of its personnel". (DUNSTAN, 2003, p. 19).

Thus, in order to solve these problems, Egypt, along with Syria, heavily invested in all of its aircraft related issues, from "anti-aircraft (AA) defenses to redress the balance in the strategic equation". (DUNSTAN, 2003, p. 19). Already in the early years of 1970's, the two Arab countries built up a large and dense system of Surface to Air Missiles (SAM) to cover both the Golan Heights and the Suez Canal, besides protecting its major cities and capitals. According to Dunstan

\footnotetext{
* International Arab Contribution from Algeria, Libya and Iraq.
} 
(2003): "A combination of the SAM-7 shoulder-fired missile and ZSU-23-4 selfpropelled anti-aircraft guns would give their ground forces greater protection in the forward combat zone". (DUNSTAN, 2003, p. 19; WILSON, 2000).

Furthermore, the Egyptians could not match Israel in an armored war, so the first one chose instead to neutralize the second, "with light anti-tank weapons ranging from the RPG-7 rocket launcher, through various recoilless rifles and antitank guns to the AT-3 'Sagger' wire-guided missile". (DUNSTAN, 2003, p. 19; WILSON, 2000). As a result, it would enable the Egyptians to inflict a heavy damage upon the Israeli army even before they crossed the Suez Canal. A summary comparison regarding Israel and Egypt's military equipment as a whole it is as follows:

\section{Table 4. Summary Comparison of Force Numbers at the Outset of the 1973 War}

\begin{tabular}{c|cc} 
Equipment & Israel & Egypt \\
\hline Personnel & 310.000 & 315.000 \\
Tanks & 2.000 & 2.200 \\
APCs & 4.000 & 2.400 \\
Artillery & 575 & 1.200 \\
ATGW & 100 & 900 \\
SAMs & 75 & 850 \\
AA Guns & 1.000 & 2.500 \\
SA-7s & - & 2.000 \\
Aircraft & 360 & 600
\end{tabular}

Source: Withdraw and adapted from Dunstan (2003, p. 27)

Egypt, in fact, considerably increased its military forces relatively to Israel, considering its last defeat in 1967, especially concerning its Air Force and its related equipment. The average amount of all Egypt's equipment listed above exceeds considerably the average amount of Israel, thus, showing an evolution de facto on the military-technological advances on Egypt's side.

Thereby, relying on the expected success of the surprise attack on two fronts at the same time (Suez Canal and Golan Heights), and producing a "sophisticated deception" to mislead the Israeli military intelligence (DUNSTAN, 2003), on October 6, 1973, the attack took place. 


\section{CONCLUSION}

This paper aimed to analyze the surprise attack/fait accompli strategy, employed by states in order to get a quick change of the status quo situation, from a military-technological standpoint. Based on the paramount contributions of Handel $(2003)$ and Dunstan $(2003,2009)$ about the uses and operations of the surprise attack, and the military-technological improvement of Egypt in the Yom Kippur War, respectively, the hypothesis was that a significant improvement in the military-technological arsenal of a given State, would increase the chances of that same state to employ a successful surprise attack against its adversary in a given conflict.

In fact, this hypothesis seems to be confirmed given the analytical results about the chosen case. The historical past of Arabs and Jews has always been marked by conflict of interests and war. Although Israel is the only Jewish state surrounded by several Arab states, the latter has showed, quite constantly, an inability of coordinating its interests regarding the existence of Israel. In terms of coordination and clarity of aims, Israel was always a step ahead regarding its neighbors. The Six Day War (1967) is an evidence of that and became a traumatic event in the Arab imaginary, given the relatively ease and shorted time that Israel defeated the Arab states.

Egypt had, for sure, a significantly deficiency in its military and technological resources by 1967 comparatively to Israel. However, this deficiency has shown to go beyond the military machinery of the Egyptian armed forces. The lack of coordination between the inner military circles of Egypt was also responsible for their defeat in the Six Day War. Considering those, it seems unlikely that even possessing a military arsenal compatible to Israel's, without the necessary technical and trained personnel, Egypt would probably still lose the confrontation with Israel.

It actually seems plausible, however, to state that the planned surprise attack against Israel indeed was, in a certain manner, influenced by the militarytechnological improvement of Egyptian and Syrians armies. The heavy and substantial investment in their air force, along with its ground forces and the degree of enhanced capability of its armored forces, seemed to give the attacking 
countries the necessary force to overpower the Israelis. In fact, it actually behaved as a "force multiplier", using Handel's (2003) terms, as long as Israel could not keep up, at the beginning, with two fronts of attack at the same time.

The comparison between the overall military forces of Israel and Egypt, at the Six Day War and the Yom Kippur War, reflects two major conclusions about the probability of success of a surprise attack based on military-technological matters. First, the enhancement of Egypt's military-technological forces and equipment, from 1967 to 1973, which surpassed considerably the Israeli forces, points out to the very confirmation that an improvement and evolution on militarytechnological factors, reduces the warning time, which increases the chances of success of a surprise attack.

Secondly, the military enhancement of a given State is not the only factor to take into consideration on an attack. The level of coordination between the domestic military leadership to its troops is also of paramount importance to the probability of success in a war. After the defeat on 1967, Egypt, along with Syria, put into practice a better planning of coordination between its own national armies as well as between the two countries. For a surprise attack of this magnitude, even with a huge enhancement on its armed forces, it is difficult to think of a tangible victory in the conflict, without a sense of necessity regarding several improvements to their military coordination. In fact, even possessing, theoretically, the better of two worlds - cutting-edge military technology and better military coordination - Egypt and Syria, by a variety of reasons, had the necessary but not the sufficient conditions to defeat the Jewish state.

\section{BIBLIOGRAPHY}

ALTMAN, Dan; 2017; By Fait Accompli, Not Coercion: How States Wrest Territory from Their Adversaries; Research Note; International Studies Quarterly, Vol. 61, ํㅜ 4, p. 881-891.

BAR- JOSEPH, Uri; MCDERMOTT, Rose; 2017. Intelligence Success and Failure: The Human Factor. Oxford University Press.

CLAUSEWITZ, Carl von. 1976. On War. Princeton, NJ: Princeton University Press, 1976, pp. 198-9. Ed. Michael Howard and Peter Paret.

DUNSTAN, Simon; 2009; The Six Day War 1967: Sinai; Osprey Publishing. 
DUNSTAN, Simon; 2003; The Yom Kippur War 1973 (2): The Sinai; Osprey Publishing.

GEORGE, Alexander L.; 1991; Avoiding War: Problems of Crisis Management; West View Press.

GEORGE, Alexander L.; SMOKE; Richard; 1974; Deterrence in American Foreign Policy: Theory and Practice; New York; Columbia University Press.

HANDEL, Michael I; 2003; Intelligence and the Problem of Strategic Surprise; Chapter 1. In: BETTS, Richard K; MAHNKEN, Thomas G. Paradoxes of Intelligence: Essays in Honor of Michael I. Handel. Frank Cass Publishers.

KAM, Ephraim; 2004; Surprise Attack: The Victim's Perspective. Harvard University Press.

KAMRAVA, Mehran; 2005; The Modern Middle East: A Political History Since the First World War; University of California Press.

LEVITE, Ariel. 1987. Intelligence and Strategic Surprises; New York: Columbia University Press.

MAIA, Eduardo; 2020; Fait Accompli Sobre Áreas Territoriais Cinzentas: Por Que Levam À Guerra? 140p. Master Thesis. Graduate Program in International Relations. Pontifícia Universidade Católica de Minas Gerais (PUC$M G)$.

PAUL, T. V.; 1994; Asymmetric Conflicts: War Initiation by Weaker Powers; Cambridge University Press.

SCHELLING, Thomas C.; 1966; Arms and Influence: With a New Preface and Afterword, 2008; Yale University Press.

SCHELLING, Thomas C.; 1960; The Strategy of Conflict; Harvard College.

TARAR, Ahmer; 2016; A Strategic Logic of the Military Fait Accompli; International Studies Quarterly 60 (4); 742-52.

WILSON, John Hughes; 2000; Military Intelligence Blunders. Carroll \& Graf Publishers. New York.

WIRTZ, James J.; 2003; Theory of Surprise; Chapter 4. In: BETTS, Richard K; MAHNKEN, Thomas G. Paradoxes of Intelligence: Essays in Honor of Michael I. Handel. Frank Cass Publishers. 